\title{
In memory of Helena Calsamiglia Blancafort
}

\section{July 1945 - October 2017}

\author{
Melissa G. Moyer \\ Universitat Autònoma de Barcelona
}

Helena Calsamiglia Blancafort passed away on October 24, 2017 after a year-long battle with cancer. She was a key figure in the introduction of Pragmatics in her birth land of Catalonia as well as in the academic circles in the rest of Spain. She organized the third IPrA conference in Barcelona in 1990 when the Association was still at its beginning and subsequently served on the IPrA consultation board until 2011.

Helena Calsamiglia Blancafort finished her undergraduate studies in Romance Philology at the University of Barcelona. In 1975 she travelled to the University of California, Berkeley with a Fulbright fellowship where she continued her training under the mentorship of John Gumperz who played a very important role in her academic and intellectual trajectory. Upon her return to Barcelona she completed her PhD on the discourse functions of verb tense in written narratives by preadolescents in the Spanish Department at the Universitat Autònoma de Barcelona.

She began her teaching career in 1973 at the Teacher's College now the Facultat de Ciències de la Educació at the Universitat Autònoma de Barcelona where her concern for the training and dissemination of knowledge about a contextualized approach to the use of language was transmitted to future teachers of primary and secondary schools. In 1994 she took up a post in the Department of Translation and Language Sciences at the newly created Pompeu Fabra University (UPF) in Barcelona where she founded the Discourse Studies Research Group (GED) that she led until 2009. She was instrumental in bringing together at the UPF a core group of international scholars among who are Teun van Dijk, John Gumperz, Lorenza Mondada with graduate students and early career academics seeking to pursue research in the field of discourse and pragmatics.

Her interest and publications related to Pragmatics include articles and book chapters on narrative, on the way language is used for the transmission of scientific knowledge as well as other specialized forms of knowledge and communication in the mass media. Her focus on these topics was on the negotiation of meaning 
and how it is accomplished through the dynamics of interaction. The book Las Cosas del Decir. Manual de Análisis del Discurso co-authored with Amparo Tusón has had an important impact in the Spanish speaking academic world beyond the frontiers of Spain.

Helena Calsamiglia Blancafort was committed to her students and she had that special quality of communicating her excitement and curiosity about language use in context. As a friend and a colleague we will miss her company, her ideas, and her collaboration in joint academic endeavors.

\section{Author's address}

Melissa G. Moyer

Dept. Filologia Anglesa i de Germanística

Universitat Autònoma de Barcelona

08193 Bellaterra, Barcelona

Spain

Melissa.Moyer@uab.cat 